\title{
NUMERICAL SIMULATION OF DEEP-DRAWING PROCESS
}

\begin{abstract}
The article deals with the analysis of formability of deep-drawing DC06 steel sheets. The aim of the investigations is to verify possibilities of formability of sheet metal with thickness of $0.85 \mathrm{~mm}$. The mechanical parameters of the sheets have been determined in uniaxial tensile and bulge tests. The numerical simulations using AUTOFORM has been carried out for two drawpiece models. Obtained results can be used during the simulation of real forming process.
\end{abstract}

Keywords: formability, numerical simulation, steel sheet

\section{Introduction}

The term process simulation describes all methods by which one or more of the process parameters are predicted approximately. The aim of the determination of these parameters is usually one or more from the following: checking the feasibility of the process design, evaluating the product properties for service use and optimize the production sequence [1].

The deep drawing process is nowadays frequently used technology of manufacturing products in industrial sphere. Many factors influence procedure of forming process. In order to optimizing this process is necessary to perform numbers of tests, which results may predict problematic and critic areas on the future product. Due to this are in industrial practice often used numerical simulations which often work on FEM principle and different time integration scheme. The most known integration schemes are static implicit and dynamic explicit integration scheme. In explicit strategy the current time step is solved once, re-

\footnotetext{
${ }^{1}$ Autor do korespondencji/corresponding autor: Janka Majerníková, Technical University of Košice, 74 Mäsiarska, Košice, Slovakia, tel.: (+421) 556023509, e-mail: jana.majernikova@tuke.sk

${ }^{2}$ Emil Spišák, Technical University of Košice, e-mail: emil.spisak@tuke.sk

3 Ján Slota, Technical University of Košice, e-mail: jan.slota@tuke.sk

${ }^{4}$ Wiesław Frącz, Rzeszow University of Technology, e-mail: wf@prz.edu.pl
} 
sulting from previous time step. Based on required accuracy the mesh is locally redefined and changed. The problem is not solved again, and the solving process is not iterated. Method is convenient for a task where the solution does not change in time [2]. Implicit strategy is in every time step starting from the previous time step and a mesh is generated using local refinement due to requiring accuracy of problem, which is calculated resulting from current mesh. This solving process is iterated until the estimated error is between the bounds of interval of requiring precision. If the time step between new iteration is not too large, the time of solving process is usually very small [2]. Nowadays, this method is indispensable in phase of production proposal, because the accuracy of results obtained during the simulation has been proved in many scientific works. Especially in cases of irregularly and complicated draws it can be the only economical way to obtain optimal parameters of production process [3, 4].

The aim of contribution is to verify possibilities of formability in the numerical simulation according to material properties of deep-drawing steel sheet reached from uniaxial and biaxial tensile tests. The numerical simulations using AUTOFORM has been realized carried out on for two drawpiece models. Obtained results can be used during realization of real forming process. In the simulation of proposed shapes of drawpieces AutoForm software with Incremental module has been used. It is used to solve exact and also very quick simulation of deep-drawing of sheet by using implicit time integration. This method is not appropriate for very quick processes, for example deformation during crash. AutoForm uses for the analysis the membrane and shell elements. The software automatically generates the discreet net. It does not need any difficult settings and corrections of the net made in this way. Considering these advantages the time of preparation of model and calculation is radically shortened.

\section{Experimental material and methods}

The simulation of deep-drawing process has been carried out for a deepdrawing DC06 BZE 75/75PHOL steel with thickness of $0.85 \mathrm{~mm}$. Experimental material has been mutually zinc-coated, with amount of zinc $75 \mathrm{~g} / \mathrm{m}^{2}$. Chemical composition of material declared by producer is: $\mathrm{C}=0.02 \%, \mathrm{Mn}=0.25 \%, \mathrm{P}=$ $0.02 \%, \mathrm{~S}=0.02 \%$ and $\mathrm{Ti}=0.3 \%$. Uniaxial tensile test has been conducted according to STN EN ISO 6892-1 standard on measuring equipment TIRA-test 2300. The specimens for tensile tests were cut under the angle of $0^{\circ}, 45^{\circ}$ and $90^{\circ}$ with respect to the rolling direction of the sheet. Values of mechanical properties, coefficient of normal anisotropy and strain hardening exponent achieved by uniaxial tensile test are shown in tab. 1. 
Numerical simulation...

Table 1. Values of mechanical properties of DC06 steel

\begin{tabular}{|c|c|c|c|c|c|c|c|c|c|}
\hline $\begin{array}{c}\text { Direction } \\
{\left[{ }^{\circ}\right]}\end{array}$ & $\begin{array}{c}\boldsymbol{R}_{p 0.2} \\
{[\mathrm{MPa}]}\end{array}$ & $\begin{array}{c}\boldsymbol{R}_{\boldsymbol{m}} \\
{[\mathrm{MPa}]}\end{array}$ & $\begin{array}{l}A_{80} \\
{[\%]}\end{array}$ & $r$ & $r_{m}$ & $\Delta r$ & $n$ & $n_{m}$ & $\Delta n$ \\
\hline 0 & 145 & 292 & 50.9 & 1.888 & \multirow{3}{*}{1.753} & \multirow{3}{*}{0.576} & 0.261 & \multirow{3}{*}{0.258} & \multirow{3}{*}{0.005} \\
\hline 45 & 151 & 298 & 47.9 & 1.464 & & & 0.255 & & \\
\hline 90 & 149 & 290 & 48.0 & 2.193 & & & 0.259 & & \\
\hline
\end{tabular}

Biaxial tension belongs to the most unfavourable schema of stress by plastic deformation of sheet. Hydraulic bulge test represents a method to obtain the stress-strain hardening curve for sheet metals. Measured signals are by means of technological card and own software program worked in graphic dependency „stress-strain”. All samples have been tested to break the material. Values of selected material parameters of DC06 steel achieved from bulge test are as follow:

- yield stress $R_{p 0.2}=143 \mathrm{MPa}$,

- ultimate strength $R_{m}=289 \mathrm{MPa}$,

- total elongation $A=59.6 \%$.

To verify the possibility of deep-drawing steel sheet formability two types of drawpieces have been proposed. Individual geometries have been made in CAD software CATIA V5. Specifically it is a "Generative Sheet Metal Design” module which contains many possibilities for creation of optimal angles, curvatures, shapes and transfer areas. The formability of deep drawing DC06 steel sheets is investigated for drawpiece types A and B (fig. 1.). In first case of drawpiece (A) the height is $50 \mathrm{~mm}$ and sheet thickness $0.85 \mathrm{~mm}$. For another variant (B) drawpiece height is $90 \mathrm{~mm}$ and sheet thickness also $0.85 \mathrm{~mm}$.

Geometry of drawing tools, blanks and breaking ribs in the simulation of deep-drawing has been deduced from 3D models of proposed variants. Basic parameters like curvature radius of the punch and the die or location and the shape of braking ribs are predefined in the model. In environment of simulation border references of tools automatically derived from imported drawpiece model are only determined. Derived geometries of drawing tools automatically generated in AutoForm with the value of punch and die offset corresponding to sheet thickness of $0.85 \mathrm{~mm}$ are shown in fig. 2.

Many models can be used for calculation of hardening curve, yield surface and determination of FLC curve. Following models have been chosen:

- hardening curve: Ludwik law - required parameters are: strain hardening exponent $n$ and material constant $K$ or yield strength $R_{e}$,

- yield surface: Hill criterion - required variables are directional values of normal anisotropy coefficients: $r_{0^{\circ}}, r_{45^{\circ}}, r_{90^{\circ}}$,

- FLC curve: model Arcelor V9 - required fields are $A_{G 90}$ and a yield strength $R_{m 90^{\circ}}$. 
Arcelor V9 model can be used for steel sheets exhibited following range of values of mechanical parameters: $R_{m 90^{\circ}}$ from 260 to $1500 \mathrm{MPa}$, sheet thickness from $0.5 \mathrm{~mm}$ to $3.5 \mathrm{~mm}$ and coefficient $r_{90^{\circ}}$ from 0.6 to 3.0 .

a)

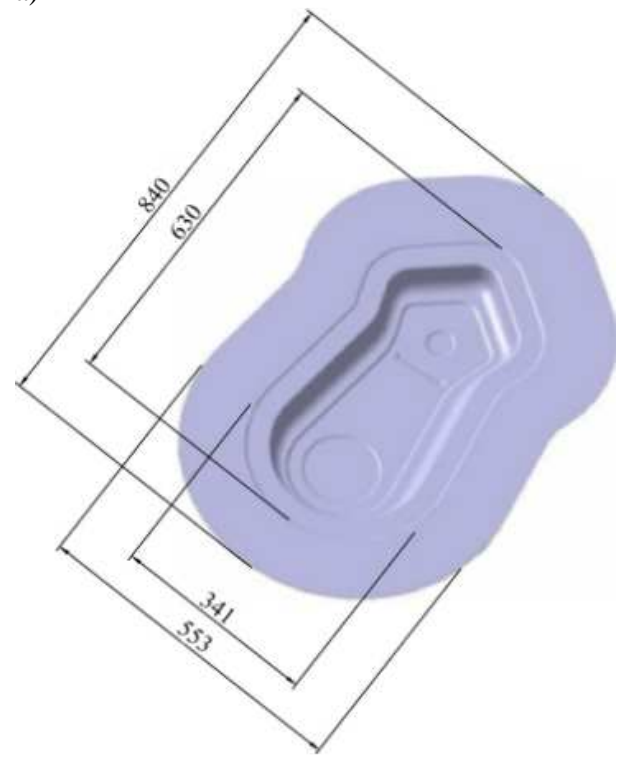

b)

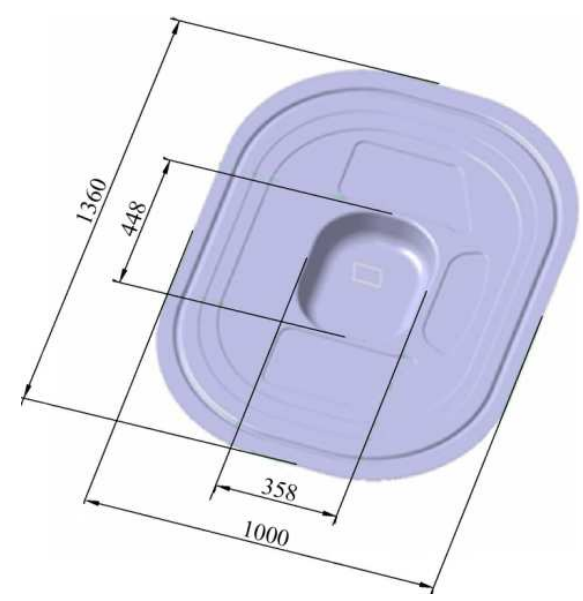

Fig. 1. Variants of drawpiece A (a) and B (b) with defined basic dimensions in mm

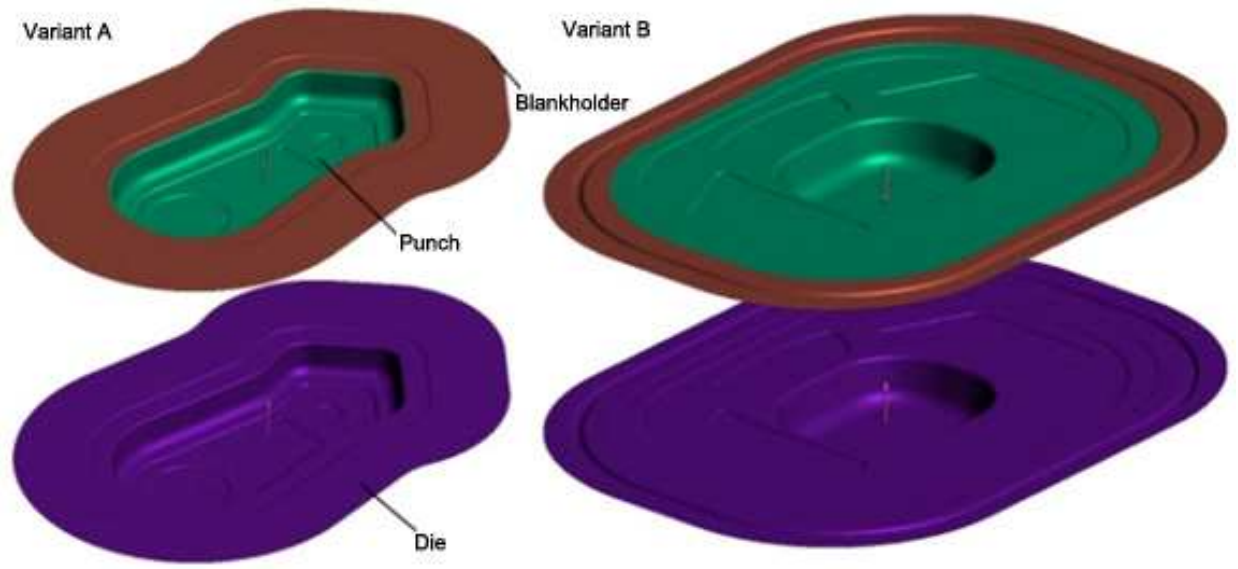

Fig. 2. Geometry of punch, die and blankholder

Complexity of each step by proposal of deep drawing process depends on complicatedness of drawpiece. For drawing simulation of proposed models the 
use of braking ribs has also been necessary. Their geometry has been also in advance proposed as a component of drawpiece. In the simulation braking ribs have been assigned to blankholder's reference. Each steps used for definition of process are following:

- definition of blank shape, material DC06 and its thickness $\mathrm{a}_{0}$ - orientation of blank in direction $0^{\circ}$ across to direction of rolling,

- definition of drawing tools references,

- definition of friction - special lubrication with coefficient of friction $\mu=0.05$ has been assumed,

- definition of movements of drawing tools for system closing and drawing, assigning of constant force for blankholder and braking ribs.

\section{Results and discussion}

AutoForm Incremental gives accurate results, where it is possible to get easily basic criterion, which shows rightness of choice of technological and constructional parameters of drawing process. It is mostly the criterion of compressibility, breaking, waving and thinning. The aim of deep drawing is to reach the biggest transformation which suppresses the unwanted effect of springback and increases the strength of drawpiece. But unwanted phenomenon like splits, excessive thinning of material, compressing of material and thickening of material must be stopped.

In the figure 3. distribution of sheet deformation and FLD diagram of the drawpiece A after shearing-off is shown. In area of the smallest radius of the basic outline is a small area (yellow colour) signalizing excessive thinning and other areas (blue colour) pointing at compression in material. As we can see on FLD diagram these areas do not represent a risk for process realization, material is mostly uniformly deformed (green area). In the figure 4. distribution of sheet deformation and FLD diagram of the drawpiece B after shearing-off is shown. As it is a model with the height of $90 \mathrm{~mm}$, the draw is considerably deforming into final shape at the expense of the thickness of the original blank (yellow area). Another defect is smaller area of strain hardening of material (green colour), which predicates its lower strength and higher rate of springback.

This analysis gives percentage thinning of draw sheet. Negative values mean the loss of thickness, otherwise positive values mean pressing of material in certain area. In figure 5. the maximum and minimum value of percentage sheet thinning is shown. Thinning in the most critical point for the draw A has the value of $0.54 \mathrm{~mm}$, which is $36 \%$ of the original thickness of $0.85 \mathrm{~mm}$. Thinning in the most critical point for the draw B has the value of $0.53 \mathrm{~mm}$, which is $37 \%$ of the original thickness of $0.85 \mathrm{~mm}$. Even if the height of the model $\mathrm{B}$ is $40 \mathrm{~mm}$ longer, difference in reduction of thickness in critical areas between both models is fractional. However the size of surface, on which is the maximum thinning, is considerably bigger at model B (green area). 
a)

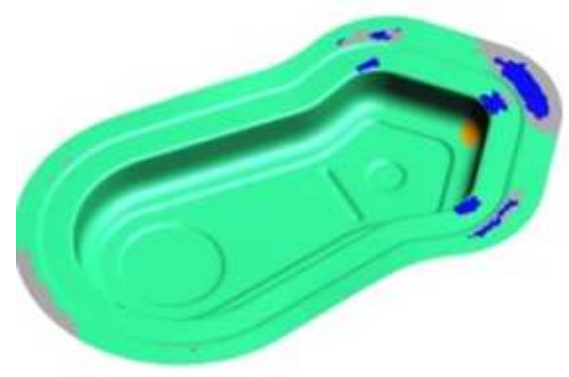

b)

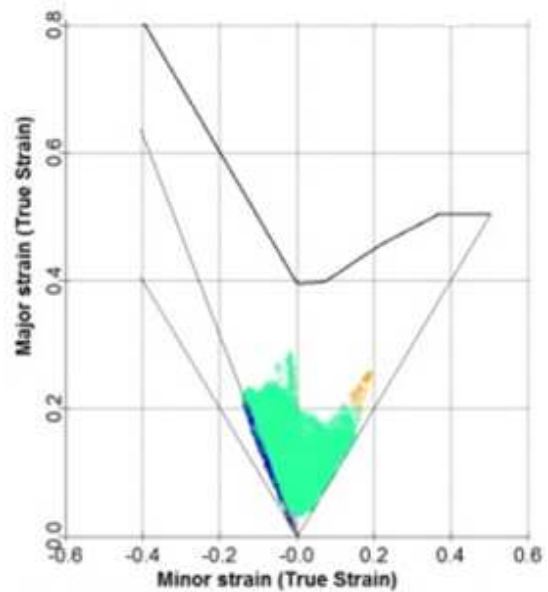

Fig. 3. Final deformation distribution (a) and FLD diagram (b) of drawpiece A

a)

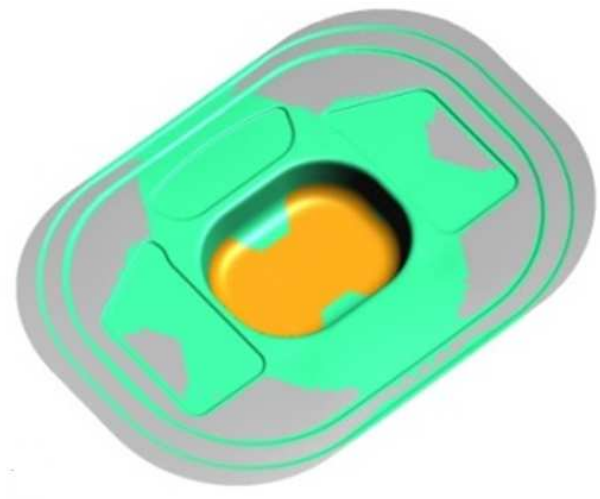

b)

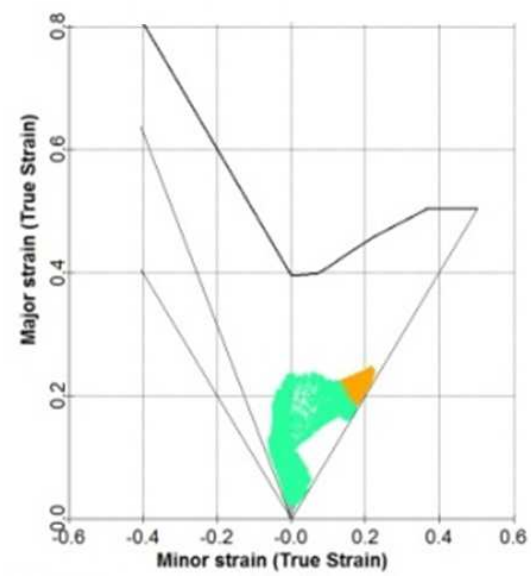

Fig. 4. Final deformation distribution (a) and FLD diagram (b) of drawpiece B

\section{Conclusions}

Development of simulation processes of steel sheets forming is aimed on increasingly exact description of fractional quantity influencing on process. Many of these have been missed at the beginning of numerical simulation or there has been not made an appropriate mathematical model. Contribution has been dealing with evaluation of formability of deep-drawing steel sheet DC06 by use of simulation with proposed models of draws with significant difference of height $(\mathrm{A}=50 \mathrm{~mm}$ and $\mathrm{B}=90 \mathrm{~mm})$. Tensile test was performed to determine 
mechanical parameters of sheet. Qualitative evaluation of results for each model of draws has been described by FLD diagrams where secondary loss of stability (waving) or possibly tertiary loss of stability (breaking) has been evaluated. Simulations lead to occurrence of waving, however these areas represent waste in their final shape. Another criterion of evaluation was analysis of thinning which did not prove splits formation not even at height of draw $90 \mathrm{~mm}$. However the size of area in which excessive thinning occurred (bigger than $30 \%$ ) is significant for model B.

a)

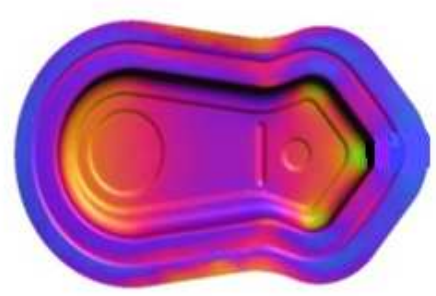

b)

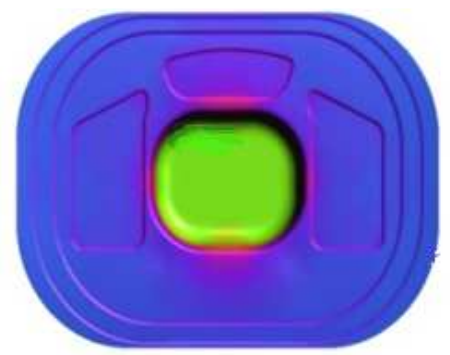

Fig. 5. Results of percentage thinning of drawpieces A (a) and B (b)

\section{Acknowledgement}

The authors are grateful to APVV for support of experimental work under grant APVV-0682-11 - Application of progressive tool coatings for increasing the effectiveness and productivity of forming sheets made of modern materials and the project VEGA no 1/0872/14 - Research and optimalization of drawing and joinability evaluation of high-strength steel sheets and aluminium steels.

\section{References}

[1] Spišák E.: Matematické modelovanie a simulácia technologických procesov - t’ahanie. Košice 2000.

[2] Koç M., Billur E., Necati C.Ö.: An experimental study on the comparative assessment of hydraulic bulge test analysis methods. Mater. Design, 32 (2011), 272-281.

[3] Atkinson M.: Accurate determination of biaxial stress-strain relationships from hydraulic bulging test of sheet metal. Int. J. Mech. Sci., 39 (1997), 761-769.

[4] Zhang J., Jiang Y.: A Study of Inhomogeneous Plastic Deformation of 1045 Steel. J. Eng. Mater. Technol., 126 (2004), 164-172. 


\section{SYMULACJA NUMERYCZNA PROCESU GŁĘBOKIEGO TŁOCZENIA}

Streszczen ie

Artykuł obejmuje tematykę analizy odkształcalności blachy stalowej głęboko tłocznej gatunku DC06. Celem badań była weryfikacja możliwości odkształcania blach o grubości $0,85 \mathrm{~mm}$. Właściwości mechaniczne blach określono w testach jednoosiowego rozciagania oraz wybrzuszania blachy. Symulacje numeryczne w programie AUTOFORM przeprowadzono dla dwóch modeli wytłoczek. Otrzymane wyniki mogą być wykorzystane do symulacji rzeczywistego procesu formowania.

Słowa kluczowe: odkształcalność, symulacja numeryczna, blacha stalowa

DOI: $10.7862 / \mathrm{rm} .2014 .59$

Otrzymano/received: 10.11.2014 r.

Zaakceptowano/accepted: 24.11.2014 r. 